\title{
Foraging interaction between monk seals and large predatory fish in the Northwestern Hawaiian Islands
}

\author{
Frank A. Parrish ${ }^{1, *}$, Greg J. Marshall ${ }^{2}$, Birgit Buhleier ${ }^{2}$, George A. Antonelis ${ }^{1}$ \\ ${ }^{1}$ Pacific Islands Fisheries Science Center, National Marine Fisheries Service, NOAA, 2570 Dole Street, Honolulu, \\ Hawaii 96822-2396, USA \\ ${ }^{2}$ National Geographic Society, 1145 17th Street N.W., Washington, DC 20036-4688, USA
}

\begin{abstract}
CRITTERCAMS were deployed on 42 Hawaiian monk seals at French Frigate Shoals, Hawaii, to assess the degree to which interaction with large predatory fish may play a role in their foraging success. Sharks, jacks, and large-bodied snappers were seen near the actively foraging seals approximately $17 \%$ of the time. Present at all but the greatest depths $(>100 \mathrm{~m})$, the predatory fish were most frequently observed when seals foraged at the summits of neighboring banks. Competing fish were encountered as individuals and in schools (mean 4.5, maximum 46 ind.) and often formed mixed-species assemblages that followed seals around. By traveling with foraging seals, the predatory fish could exploit the seals' superior ability to flush cryptic prey from bottom cover. The probing, digging, and rock-flipping activities of seals spook prey into the open, making them available to jacks, sharks, and snappers. The jacks Caranx ignobilis and Seriola dumerili were the most successful at obtaining prey items flushed from cover by the seals, but carcharhinid sharks were also seen competing for prey. Some adult seals appeared to feed effectively in prey-rich areas despite the presence of high densities of predatory fish. It is not known if the predatory fish have a larger impact on juvenile seals, the segment of the population with the poorest survivorship.
\end{abstract}

KEY WORDS: Hawaiian monk seal · Monachus schauinslandi · Competition · Klepto-parasitism • CRITTERCAM $\cdot$ Endangered species $\cdot$ Apex predators $\cdot$ Sharks $\cdot$ Jacks

\section{INTRODUCTION}

The foraging success of the endangered Hawaiian monk seal Monachus schauinslandi at French Frigate Shoals Atoll (FFS) has been a focus of study for 2 decades (e.g. DeLong et al. 1984, Goodman-Lowe 1998, Parrish et al. 2002, Littnan et al. 2004, Stewart et al. 2006). Although the largest subpopulation of monk seals persists at this atoll, its numbers have steadily declined there, following a decrease initially identified in the late 1980s and early 1990s (Gilmartin et al. 1993, Gilmartin \& Eberhardt 1995). Subsequent demographic studies by Ragen \& Lavigne (1999) identified juvenile seals as the segment of the population with the lowest survival (Antonelis et al. 2006). Size at weaning was correlated with survival for most cohorts
(Craig \& Ragen 1999), and the overall poor body condition of juvenile seals has been primarily attributed to starvation rather than disease (Reif et al. 2004, Aguirre et al. 2007).

Recent studies have focused on various aspects of monk seal foraging behavior and have included scat analysis to define diet (Goodman-Lowe 1998, Longenecker et al. 2006), satellite telemetry to define oceanic movement, analysis of dive patterns to describe foraging behavior (Stewart et al. 2006, Parrish \& Abernathy 2006), use of seal-mounted video cameras to understand prey selection and habitat use (Parrish et al. 2000, 2002, 2005), and evaluation of oceanographic factors to assess potential influences on prey resources and seal survival (Schmelzer 2000, Antonelis et al. 2003, Baker et al. 2006). There is also a growing appre- 
ciation that the NWHI (Northwestern Hawaiian Islands) is one of the few remaining apex-dominated marine ecosystems (Sudekum et al. 1991, Friedlander \& DeMartini 2002) that has prompted interest in the degree of inter-specific competition for prey between monk seals and large predatory fish of the region. The unusually high number of sharks, jacks, and snappers in the NWHI is associated with the regional absence of fishing and exerts uncommon top-down pressure on the reef ecosystem (Sudekum et al. 1991, Friedlander \& DeMartini 2002, Parrish \& Boland 2004, DeMartini \& Friedlander 2006). Data obtained from diet studies of the monk seal (Goodman-Lowe 1998), sharks (DeCrosta et al. 1984), and jacks (Sudekum et al. 1991) indicate that these predators feed in similar habitats on the same prey types and thus, at times, may compete for the same resources. Inter-specific competition is difficult to document for highly mobile species that are concealed from view underwater. Seal-mounted video cameras such as National Geographic Television's CRITTERCAM (Marshall 1998) affords one method to address the topic. Eight years of research using CRITTERCAMs on monk seals at French Frigate Shoals to identify various aspects of seal foraging behavior has generated a sizable sample of video recordings of interactions between seals and predatory fish. In the present study, we investigate the level of apparent inter-specific competition among seals and predatory fish by defining the frequency of interactions, identifying the size and species involved, and determining the habitat in which the interactions occurred.

\section{MATERIALS AND METHODS}

Study site. FFS is a crescent-shaped atoll bounding a lagoon with a barrier reef running along its northern perimeter and diagonally through its center (Fig. 1). The sand islets located along this diagonal barrier reef are the only land that monk seals have within a 60 mile radius on which to haul out. During summer and fall months of 1995 to 2002, 42 monk seals (adults and juveniles) were captured, sedated with diazepam, and instrumented with programmable digital video cameras (CRITTERCAM: National Geographic Missions Program, Wild Insight Venus UTPR [Underwater Timed Picture Recorder]) using 10-min epoxy to glue the units to the dorsal pelage (Parrish et al. 2000). The camera was oriented such that the field of view was forward, with the seal's head just visible at the bottom of the image (Fig. 2). The size of the instrument deployed depended on the size and maturity of the seal (Table 1), with the smaller instruments attached to juvenile seals. The camera units also included very high frequency radio tags and time depth recorders.
Such instrumentations have been shown not to compromise seal survival or ability to forage (Baker \& Johanos 2002, Littnan et al. 2004). Sedated seals remained awake during the entire procedure and returned to the water unassisted immediately after recovering from the sedative. The entire procedure never exceeded $60 \mathrm{~min}$. Seal haul-out behavior and location was monitored every $3 \mathrm{~h}$ throughout each deployment from the northwest end of the atoll at Tern Island, FFS. The cameras were recovered by recapturing each seal; the time between deployment and recapture ranged between 1 and $10 \mathrm{~d}$ following instrumentation.

Seal dive depths were digitally logged every $10 \mathrm{~s}$ throughout the camera deployment. The video cameras were programmed to record segments of images and sound for 6 min each daylight hour (1.5 min were recorded every $15 \mathrm{~min}$, or $3 \mathrm{~min}$ every $30 \mathrm{~min})$. A sea water conductivity and depth/pressure switch $(<1 \mathrm{~m})$ was used to cease recording when the seal was on the beach or at the surface to maximize collection of images during foraging activity. If the seal surfaced while the camera was still recording, the segment was interrupted and the tape saved for future recording segments. The total surveillance time for the seals ranged from 36 to $72 \mathrm{~h}$ depending on the size of the tape cartridge used and the amount of time the seal spent at sea. Five seals were fitted with night vision CRITTERCAMs, and the sampling was limited to evening hours only. The night vision systems were able to 'see' the bottom area extending $3 \mathrm{~m}$ in front of the seal (Parrish et al. 2002).

Scoring of data. Video images were reviewed and scored into a set of standardized variables entered into a relational database. For each video segment, the depth, type of seal behavior (e.g. swimming, resting, bottom-searching), type of habitat (e.g. atoll, bank, open ocean), feeding events, and the maximum number of predators present were recorded. The forwardfacing mount of the camera could not document the presence of 'following' predators, and thus the count of fish predators is unavoidably biased low. Side-to-side motion of the seal's head as it passed over the bottom was clearly swimming behavior. Segments showing the seal motionless on the sea floor, often under a ledge or in a cave, were classified as resting behavior. Bottom-searching behavior was quantified for each segment by scoring the number of times that the seal probed the substrate with its muzzle (standardized for observation time) while moving along the sea floor. The maximum number of predatory fish was the greatest number present on screen at any one time during the video segment. Behaviors of the predatory fish were binned into 4 different classes: 'escort' — the fish were clearly swimming in association with the seal, 


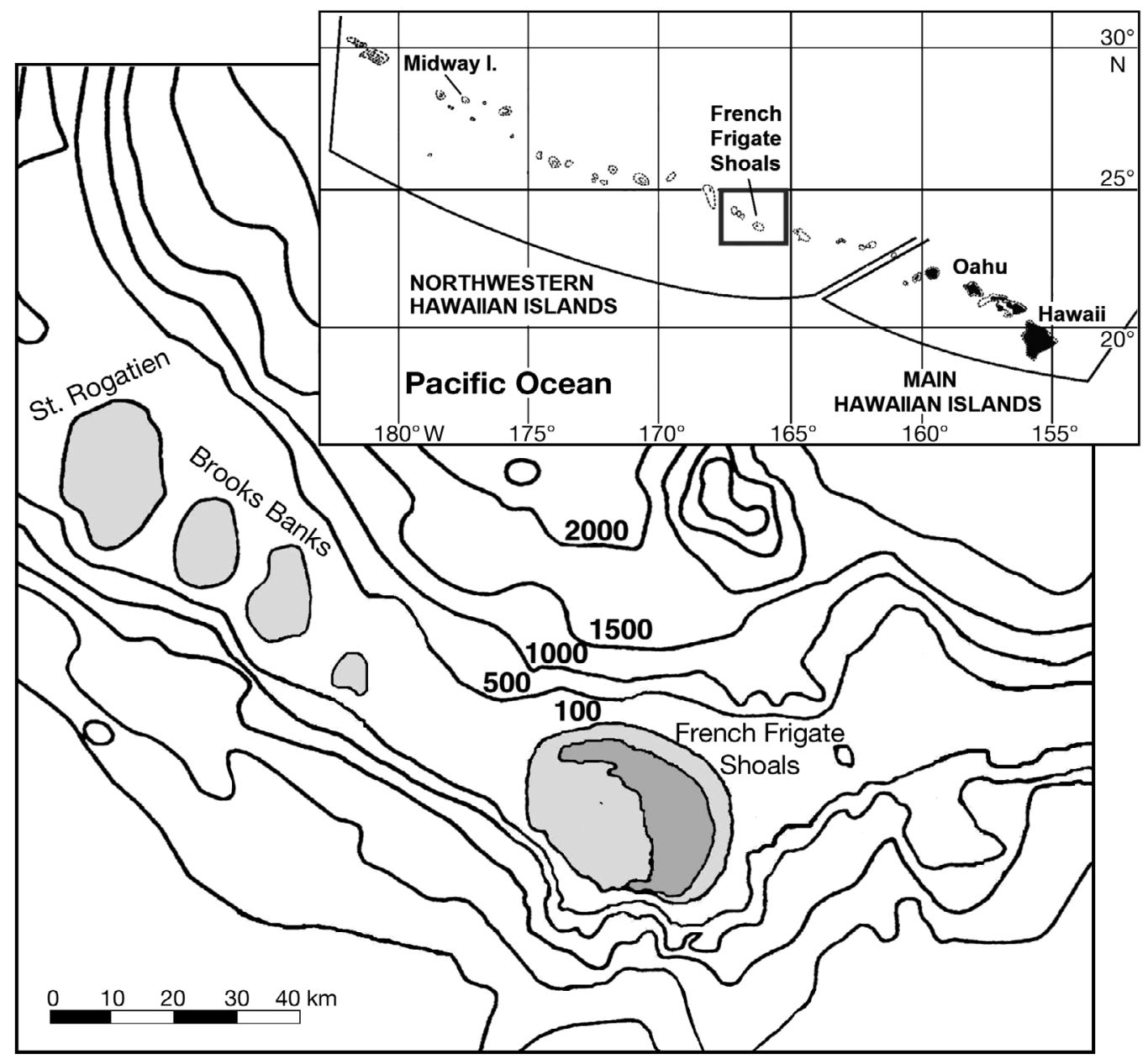

Fig. 1. Hawaiian Archipelago with the French Frigate Shoals region expanded to show the atoll (dark grey) and neighboring banks (light grey). Contour depths in $\mathrm{m}$

visible either in front or peripherally; 'in-face' - the predatory fish nosed in close to the mouth of the seal while the seal probed the bottom for food; 'feeding' fish was consuming a prey item; and 'stealing' — fish either took or attempted to take a prey item from the mouth of the seal.

Analysis. Descriptive statistics were used to summarize monk seal encounters with predatory fish. For comparison the numbers of competing fish tallied from the video were standardized by the run time of each image segment. Mean values were used in the comparisons of individual seals to avoid possible effects of consecutively recorded video segments. Data that violated assumptions of homogeneity or were not normally distributed were analyzed using nonparametric techniques (Siegel \& Castellan 1988). Statistical significance for all comparisons was set at 0.05 . The smallest sample size used in comparisons permitted assessments of significant effects (effect size $=0.50$ ) with a power of 0.66 .

\section{RESULTS}

A total of 3192 video segments were collected comprising $69 \mathrm{~h}$ of underwater surveillance with a mean of $1.7 \mathrm{~h}( \pm 0.9 \mathrm{~h} \mathrm{SD})$ per seal. The mean duration of video segments was $83 \pm 47 \mathrm{~s}$ ). Twenty-two percent of the video segments were low-light images collected during crepuscular hours of the daytime video sampling or at night when the night-vision cameras were recording images. Video segments showed that jacks Caranx ignobilis, Seriola dumerili, Caranx melanpygus were the predatory fish species most frequently encountered (mean $0.19 \pm 0.55$ video segments seal ${ }^{-1}$ ) (Fig. 3). The jacks were easily identifiable by their bold movements, often approaching the seals head on. The next most common predator was the large-bodied grey snapper Aprion virescens $\left(0.10 \pm 0.48\right.$ segments seal $\left.{ }^{-1}\right)$, also easily distinguished. Carcharhinid sharks were the third most common predatory fish $(0.02 \pm 0.03$ video segments seal ${ }^{-1}$ ) but were difficult to identify at 


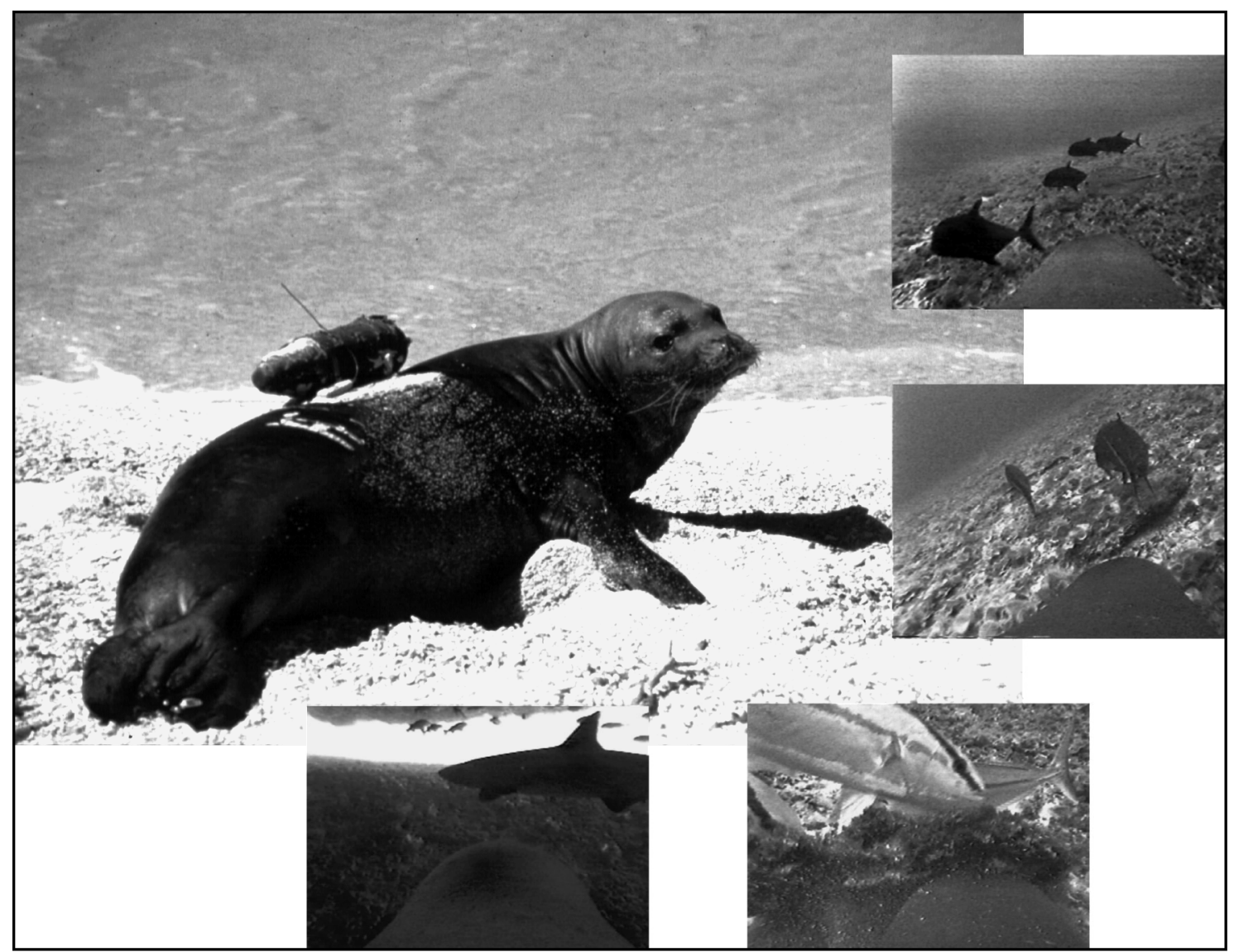

Fig. 2. Monachus schauinslandi. Photo of Hawaiian monk seal fitted with a CRITTERCAM. Insets are video captures from the camera showing 'escort' of Caranx ignobilis (top 2), 'in face' behavior of Seriola dumerili (bottom right), and a carcharhinid shark (bottom left). The top of the seal's head is visible at the bottom of each frame

Table 1. CRITterCAM deployments by year with number of seals (n), seal age, class, sex, camera size, and surveillance parameters. CCAM = CRITTERCAM, Venus UTPR

\begin{tabular}{|c|c|c|c|c|c|c|c|}
\hline \multirow[t]{2}{*}{ Year } & \multirow[t]{2}{*}{$\mathrm{n}$} & \multirow[t]{2}{*}{ Seal age } & \multirow[t]{2}{*}{ Sex } & \multirow{2}{*}{$\begin{array}{c}\text { Camera } \\
\text { (kg in air) }\end{array}$} & \multirow{2}{*}{$\begin{array}{l}\text { Camera size } \\
(\mathrm{cm})\end{array}$} & \multicolumn{2}{|c|}{ Surveillance } \\
\hline & & & & & & Sampling & Day/Night \\
\hline \multirow[t]{2}{*}{$1995-97$} & 5 & Adult & M & $\begin{array}{c}\text { CCAM } \\
(2 \mathrm{~kg})\end{array}$ & $35 \times 10$ & $180 \mathrm{~s} / 30 \mathrm{~min}$ & Day \\
\hline & 22 & Adult & M & $\begin{array}{c}\text { CCAM } \\
(2 \mathrm{~kg})\end{array}$ & $35 \times 10$ & $90 \mathrm{~s} / 15 \mathrm{~min}$ & Day \\
\hline 2000 & 5 & Adult & M & $\begin{array}{l}\text { CCAM } \\
(2.5 \mathrm{~kg})\end{array}$ & $45 \times 10$ & $180 \mathrm{~s} / 30 \mathrm{~min}$ & Night \\
\hline \multirow[t]{2}{*}{2002} & 1 & Adult & M & $\begin{array}{l}\text { VENUS } \\
(0.75 \mathrm{~kg})\end{array}$ & $15 \times 15$ & $90 \mathrm{~s} / 15 \mathrm{~min}$ & Day \\
\hline & 9 & Juvenile & $\mathrm{M}$ and $\mathrm{F}$ & $\begin{array}{l}\text { CCAM } \\
(1.08 \mathrm{~kg})\end{array}$ & $25 \times 7.5$ & $90 \mathrm{~s} / 15 \mathrm{~min}$ & Day \\
\hline
\end{tabular}

the species level, with the exception of white-tip reef shark Triaenodon obesus, which were mostly recorded when seals rested in underwater caves. At night, the grey snapper was seen once, sharks were seen in 5 segments and jacks were present in 22 of the sampling segments.

\section{Patterns in predatory fish encounters}

Overall, $0.0037 \pm 0.007$ predatory fish were seen per video segment per seal. Their presence in similar numbers and sizes on adjacent video segments suggests that many of the predatory fish seen are the same indi- 
viduals being recorded repeatedly, but this is difficult to verify. When present on video, they averaged $4.5 \pm 6.4$ ind.; the highest number recorded in a single frame was 46. The snappers, jacks and sharks were terminal phase adults (sizes listed in Fig. 3) and often schooled inter-specifically. Most of the video data (total duration $55 \mathrm{~h}$ ) were collected at the atoll where the seals were instrumented, but some seals $(n=11)$ spent time in the open ocean $(7.9 \mathrm{~h})$ and on the summits of neighboring banks ( $\mathrm{n}=9 ; \sim 5.9 \mathrm{~h}$ ). The highest densities of predatory fish were recorded accompanying adult seals that were foraging on the neighboring bank summits (Fig. 4). They were clearly attracted to the intense bottom-searching activities near the seal's head and anterior, where their presence was easily recorded. The degree to which this attraction inflates the numbers of predatory fish on the video was tested in an analysis of covariance (ANCOVA) using location (atoll, bank, open ocean) as a fixed effect and the rate of seal bottom-searching behavior as a covariate. The bottom-searching covariate narrowly missed significance in explaining the numbers of predatory fish $(F$ $(1,42)=3.4 ; \mathrm{p}=0.08 ; \mathrm{r}=0.11)$. A follow-up analysis controlling for bottom-searching behavior showed that the mean numbers of predatory fish were primarily linked to the location variable $(F(2,42)=286.3$, p < 0.001), indicating that seals feed at certain sites even though they have high densities of predatory fish. Removing the effect of location, by looking at data only from the banks, revealed the attraction-influence, with the number of predatory fish correlated with seal bottom-searching behavior $\left(\mathrm{r}_{\mathrm{s}}=0.53, \mathrm{p}<0.001\right)$.

The depths at which seals encountered predatory fish differed from the overall depth distribution of the

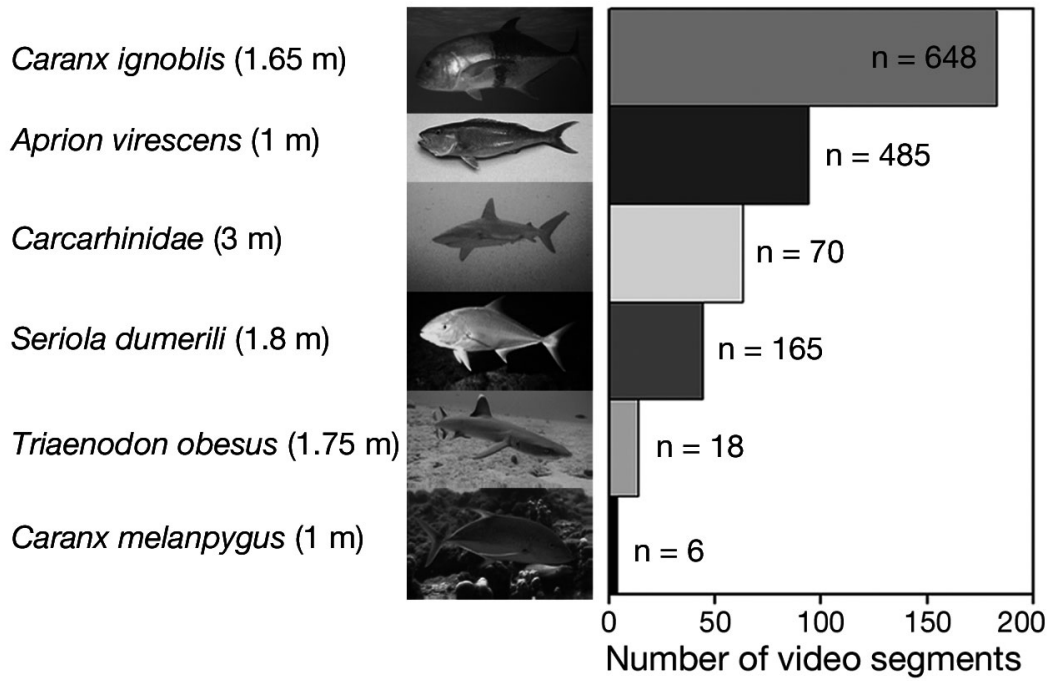

Fig. 3. Histogram showing the frequency (n) of predatory fish recorded on video. The maximum total length as reported in the literature (Randall 2007) is (in parentheses) listed for each taxon seals' movements (Wilcoxon Signed-Rank $Z=-3.9$, $\mathrm{p}<$ 0.001) (Fig. 5). All predators were seen at depths shallower than $100 \mathrm{~m}$. Encounters with predators peaked at 60 to $80 \mathrm{~m}$ for jacks and snappers (Fig. 5, inset). Seal dive activity at the atoll extended deeper $(>200 \mathrm{~m})$ than at the neighboring banks (90 $\mathrm{m}$ ) and a comparison of seal diving patterns in the overlapping depth range $(0$ to $90 \mathrm{~m}$ ) showed that diving patterns between the atoll and bank did not significantly differ (Wilcoxon $Z=$ $-0.14, p=0.88$ ). There was also no significant difference in the depth distribution of predatory fish encountered between the atoll and neighboring banks (Wilcoxon $Z=-0.968, \mathrm{p}=0.333$ ).

During the present study monk seals were never seen engaged in interference competition. Competing predatory fish were recorded on $17 \%$ of the video footage for the 42 seals. The prey, bottom-associated fish and invertebrates, were observed burrowed deep in the sand or hiding under rocks and thus presumably otherwise unavailable to the jacks and sharks. A total of 96 feeding events by monk seals were documented: 70 on the slope surrounding the atoll, 25 on the neighboring banks, and 1 from open ocean subphotic depths. In a number of cases it was possible to use the seal's prey handling to deduce successful capture of the prey items that were blocked from view.

\section{Impact of predatory fish}

Escort behavior was the most common behavior noted for the predatory fish taxa (Fig. 6). In almost all cases, predatory fish escorted the seals; however, in rare instances $(n=3)$, seals specifically traveled to a location where jacks or snappers were inspecting the bottom. Video segments with predatory fish were normalized to compare predator encounter rates. Aprion virescens were encountered at a mean rate of $4 \pm 5.6 \mathrm{~min}^{-1}$; they maintained more than a body length of distance from the seal and never moved near the seal's head to compete for prey. Jacks were the closest escorts, both as individuals and in schools. Typically, a jack escorting a seal would be less than a body length from the seal's head (assuming it had not been displaced by other jacks competing for the position closest to the seal). The mean encounter rate for jacks was $3.4 \pm 6.48$ $\mathrm{min}^{-1}$. Jacks routinely positioned their mouths within inches of the seal's nose to maximize their chances of snatching prey items flushed by the bottom prob- 


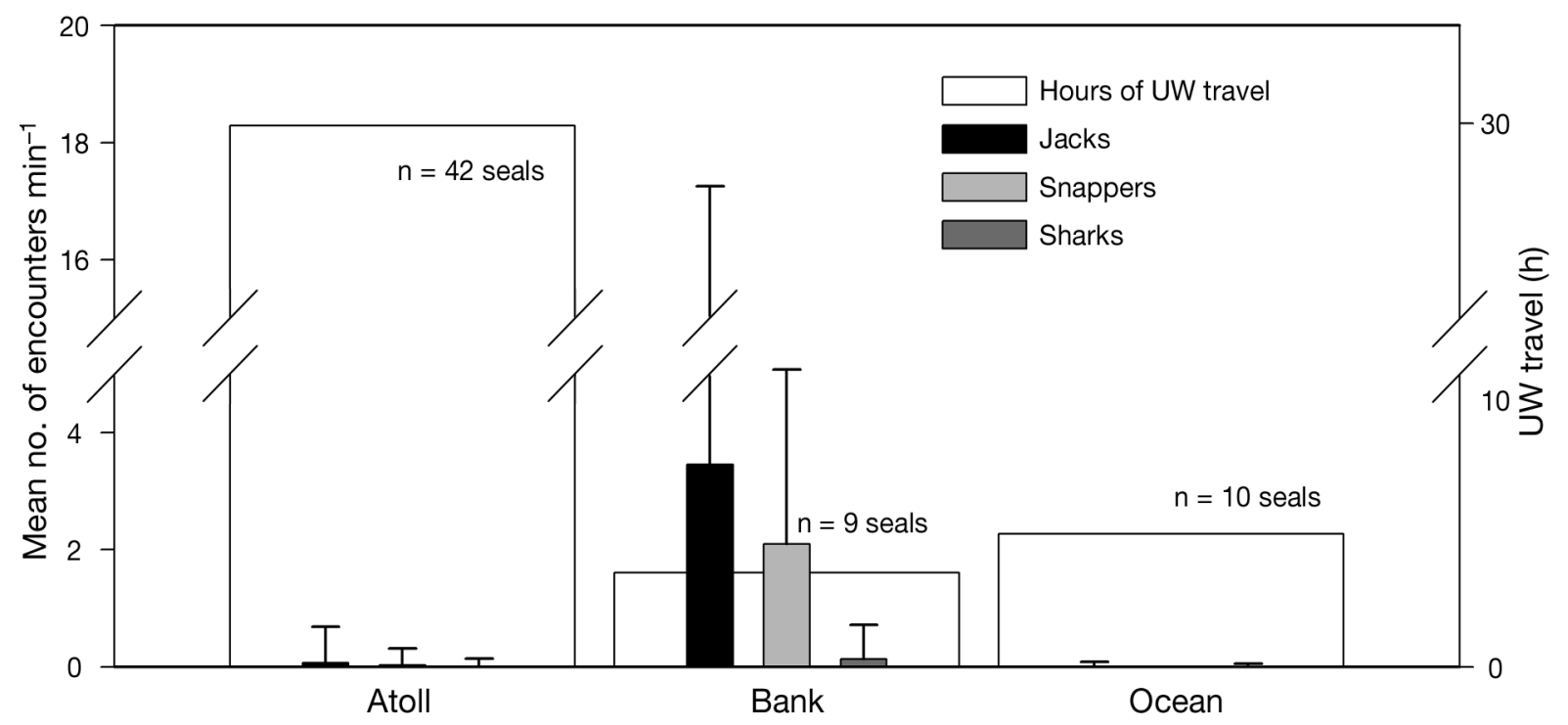

Fig. 4. Comparison of the encounter rate $( \pm \mathrm{SD})$ for predatory fish recorded at the atoll, neighboring banks, and in the open ocean showing hours spent by seals at each of the 'habitats' (right axis) and the mean number of encounters min ${ }^{-1}$ for snappers, jacks, and sharks. UW: underwater

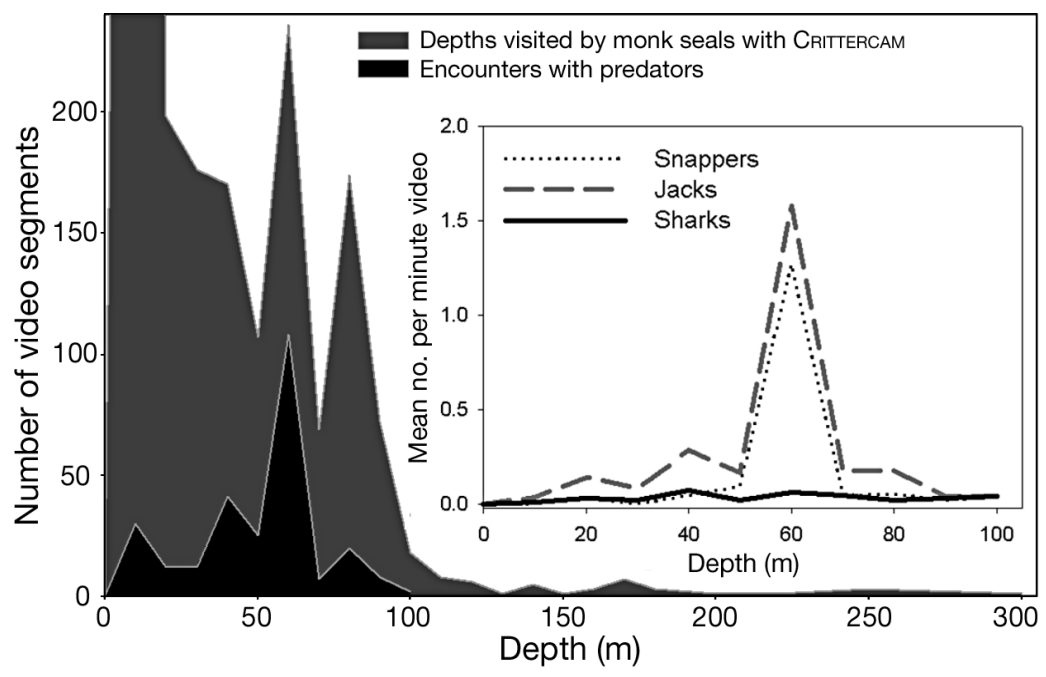

Fig. 5. Depth distribution of predatory fish seen on video in relation to the seals' total diving activity. Inset shows the depth distribution of snappers, jacks and sharks in the 0 to $100 \mathrm{~m}$ depth range wherein all the predatory fish were seen

ing of the seal. Jacks were routinely observed to capture prey (30 occasions) before the seal could catch it. Sharks were encountered at the lowest rate (mean 0.9 $\pm 0.5 \mathrm{~min}^{-1}$, but they also tended to trail behind the seals in areas where they were less likely to be recorded by the video. This could mean the magnitude of bias varies among predator species (e.g. the bias is generally greater for sharks than for jacks). Sharks were seen to move in, close to the seal's mouth, when they were not displaced by the more aggressive jacks. In one segment, a large shark ( $>2 \mathrm{~m})$ bumped the feeding seal multiple times in an attempt to prompt the seal to drop a fish it was handling.

There were many images of the predatory fish and the seal going after the same prey item, but none of the predatory fish were observed taking a prey item from the seal's mouth. Comparing the seals' overall mean foraging success (capture of prey items) with and without predatory fish showed greater feeding success in the presence of predators (Mann Whitney $U=185386, Z=-13.2, \mathrm{p}<0.001)$. The most intense feeding was exhibited by adult seals, who visited the neighboring banks where the highest numbers of predatory fish were observed $(3.4 \pm 0.8$ $\min ^{-1}$ i). The adult seals were clearly capable of obtaining prey, even in the presence of numerous predatory fish. Since juvenile seals did not visit the banks, the comparison was rerun for the mix of adult and juvenile seals at the atoll, where there were fewer predatory fish (mean $0.10 \pm 0.05 \mathrm{~min}^{-1}$ ), and no impact was found (Mann Whitney $U=75, Z=-3.4, \mathrm{p}<0.01$ ). A follow-up comparison of prey capture success between the atoll's adult and juvenile seals also showed no significant difference (Mann Whitney $U=91$; Wilcoxon $W=497$, $Z=-1.45, \mathrm{p}=0.226)$. Despite these findings it is important to remember that the density of predatory fish was considerably less at the atoll, so the effectiveness of juveniles foraging among competitors is uncertain. 


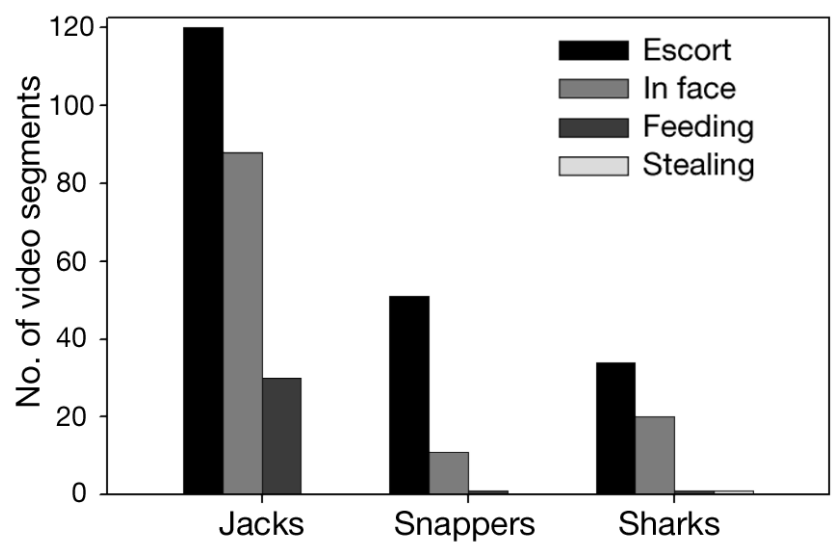

Fig. 6. Number of video segments classified according to type of competitive behavior exhibited by sharks, snappers and jacks. See 'Materials and methods' for a description of behaviors

\section{DISCUSSION}

\section{Animal-borne video sampling}

Animal-borne imaging provides an exciting source of data at an unprecedented resolution. It makes possible considerations of habitat type, depth, foraging technique, and the effects of the assemblage of competing predatory fish. It also presents some unique challenges for interpretation and analysis. Using the maximum number of predatory fish recorded in an image frame eliminates recounting of fish within the same video segment, but it is likely some fish were recounted on consecutive video segments. Because predatory fish are attracted to the seal, their presence is typically detected in the first few seconds of the video segment. Longer duration segments provide a greater chance that the camera will capture greater numbers of the predatory fish in a single image frame. In situations with numerous predatory fish the longer the recording time, the greater the number that will be detected, thus improving the abundance count. In cases with few predatory fish the abundance count is less influenced by the recording time. Consequently, the overall probability of capturing predatory fish on video varies with the recording duration and number of predatory fish present. Maximum number, time-offirst-arrival and other image analysis strategies have been effectively used in baited video camera surveys (Ellis \& DeMartini 1995). The latter have achieved comparable video data by using standardized orientation and sampling duration in camera deployment. In our case, the attempt to standardize the deployments of animal-borne imaging is further compounded by the dynamic and often unpredictable nature of the monk seals.

\section{Predatory fish encounters}

Adult seals generally seem indifferent to the jacks, sharks, and snappers, despite the number and proximity of these fish. It is clear that these predatory fish are part of the seal's foraging landscape. Although the adult seals are larger than most of the competing fish, the juvenile seals are roughly the same size and could have a difficult time capturing prey in the presence of the competitors. To the competing predatory fish, monk seals are an exploitable foraging resource. Snappers, sharks, and especially jacks are quick and more agile than the seals, but they showed much less capacity to detect and flush benthic prey from cover. The seals use their whiskers to brush along the bottom and chase out camouflaged prey (Table 2). They can also dig out wrasses and eels that are buried deep in the sand bottom and they easily flip large rocks $(\sim 20 \mathrm{~kg})$ to obtain prey items hiding beneath. The jacks' awareness of such behavior enables them to swim ahead of the seal and wait near a rock until the seal arrives, moves the rock and flushes prey items from cover.

The numbers of predatory fish varied greatly between video segments. Underwater visual surveys in the NWHI (Friedlander \& DeMartini 2002, Parrish \& Boland 2004, Holzwarth et al. 2006) by divers are the closest data sets we have to compare with the predatory fish abundances recorded on the CRITTERCAM videos. Intuitively, we might think the observations made by divers and videos from instrumented monk seals should differ greatly, but our notions are surely less important than how the predatory fish (jacks, sharks, and snappers) perceive monk seals and similarly sized scuba divers. The predatory fish of the NWHI have had little or no exposure to boats and divers and thus exhibit bold behavior, enhanced by a history of following and competing with monk seals for prey. Treating the CRITTERCAM video segments as inde-

Table 2. Mean body length of prey families observed consumed by seals fitted with cameras

\begin{tabular}{|lc|}
\hline Body length $(\mathrm{cm})$ & Prey items \\
\hline $5-10$ & Bothidae \\
& Canthigasterdae \\
& Apogonidae \\
& Pomacentridae \\
$10-20$ & Labridae \\
& Balistidae \\
& Holocentridae \\
& Acanthuridae \\
$20-30$ & Octopoda \\
& Congrogadidae \\
& Muraenidae \\
& Pentacerotidae \\
\hline
\end{tabular}


pendent underwater visual surveys (search area estimate $50 \mathrm{~m}^{2} \mathrm{~min}^{-1}$ ), the mean number of predatory fish recorded by the CRITTERCAM ranges from a value that is consistent with the number of predators reported in diver visual surveys of the atoll to an unrealistically high value on the nearby banks, where the seals foraged most intensively and encountered the highest density of predatory fish (Table 3). The estimate of predatory fish density from the CRITTERCAM will be dependent on the number of predatory fish present and the attraction of the fish to the seal and its foraging activities. The ANCOVA that assessed foraging success by location and bottom searching indicated that the highest encounter rate with predatory fish was primarily a result of location effect (i.e. bank summits) and, to a lesser degree, the attraction to the seals' intense bottom-searching behavior. It is possible that the abundances of predatory fish are highest in preyrich patches, and thus seals are confronted with more competitors if they choose to visit prey-rich patches. Competing with predatory fish at the banks and other prey rich locations is an inherent cost that the seals will endure as long as their foraging success exceeds that experienced at other locations with lower prey density.

The absence of predators during the seals' oceanic transits, or when they foraged deeper than $100 \mathrm{~m}$, suggests the predator aggregations have some spatial fidelity. Regional tracking and tagging studies have shown no evidence of interisland movement for jacks (Tagawa \& Tam 2006, Meyer et al. 2007a), snappers (Meyer et al. 2007b), and some sharks (Lowe et al. 2006). The deep water that separates the atoll from the banks and seamounts is a sizable barrier that may discourage predatory fish from following seals during their oceanic transits. The absence of predatory fish on the CRITTERCAM video at depths below $100 \mathrm{~m}$ could be an important consideration in the seals' foraging landscape. The bulk of predatory reef fish are typically found above the thermocline (Thresher \& Colin 1986, Chave \& Mundy 1994), so any seals foraging deep may reduce, if not avoid, competition. Surveys of the slope (Kelley \& Ikehara 2006) and subphotic depths (Parrish 2006) in the NWHI indicate fewer predatory fish than the numbers seen at shallower depths. One survey of predatory fish abundance at the bank closest to FFS used a submersible to travel from the $500 \mathrm{~m}$ contour to the $60 \mathrm{~m}$ summit and encountered only 2 Seriola dumerili deeper than the summit; at the summit, a school of >50 Caranx ignobilis and Aprion virescens were encountered (F. Parrish unpubl. data).
Seals instrumented in satellite telemetry studies have been documented routinely diving below $100 \mathrm{~m}$ to forage on the mesophotic slope and in subphotic depths (Stewart et al. 2006). Whether the seals are going to these sites to exploit higher prey density or to avoid aggregations of predatory fish, or both, is unknown. Deep diving by monk seals has been documented since the first trials of telemetry work (DeLong et al. 1984, Schlexer 1984). Thus, monk seals may have always foraged in deepwater habitats below $100 \mathrm{~m}$, but the extent to which such diving has changed over time is not known because there are no other extensive historical dive data sets that can be compared with the recent comprehensive studies (Abernathy 1999, Stewart et al. 2006).

\section{Impact of predatory reef fish}

Not all of the competitors exerted equal impact on the seals' foraging efforts. Snappers showed interest in the seals' activities but did not actively pursue the same prey item as the seals. Their strategy was to capture other prey items flushed from cover by the seals' activities. Jacks and sharks were seen pursuing the same prey items that the seals were targeting. The lack of instances of prey being taken from the seals by predatory fish indicates that the seals are adept at handling prey once the prey items have been caught, but they are also threatened with competition at the point of prey capture. There were 30 instances where prey items flushed from cover by the seals were consumed by the competing predatory fish before the seals could obtain them. Had the competitors not been present, this prey would have been available to the monk seals. Numerous images show adult seals mitigating loss of prey by deftly tipping large rocks and slipping their heads underneath to eat the small fish hiding under the rock, while the competing jacks crowd around the edges of the rock trying unsuccessfully to get at the

Table 3. Comparison between densities of predatory fish seen on diver surveys in the Northwestern Hawaiian Islands (NWHI) and densities of predatory fish estimated from the CRITTERCAMS. FFS: French Frigate Shoals

\begin{tabular}{|c|c|c|c|c|c|}
\hline Survey type & Location & $\begin{array}{l}\text { Depth } \\
\text { (m) }\end{array}$ & $\begin{array}{l}\text { Density }(\mathrm{r} \\
\text { Mean }\end{array}$ & $\begin{array}{l}\text { o. } \mathrm{ha}^{-1} \text { ) } \\
\mathrm{SD}\end{array}$ & $\begin{array}{l}\text { Predator survey } \\
\text { in the NWHI }\end{array}$ \\
\hline Belt transect & Atoll & $<20$ & 132 & 314 & $\begin{array}{l}\text { Friedlander \& DeMartini } \\
\qquad(2002)\end{array}$ \\
\hline Point count & Bank & $30-40$ & 42 & 66 & Parrish \& Boland (2004) \\
\hline $\begin{array}{l}\text { Towed-diver } \\
\text { survey }\end{array}$ & $\begin{array}{l}\text { Atoll } \\
\text { Bank }\end{array}$ & $\begin{array}{l}<20 \\
<30\end{array}$ & $\begin{array}{c}53 \\
13.6\end{array}$ & $\begin{array}{c}67 \\
60.7\end{array}$ & Holzwarth et al. $(2006)^{a}$ \\
\hline CRITTERCAM & $\begin{array}{l}\text { Atoll } \\
\text { Bank }\end{array}$ & $\begin{array}{c}0-100 \\
40-100\end{array}$ & $\begin{array}{c}39 \\
187\end{array}$ & $\begin{array}{l}1738 \\
4475\end{array}$ & $\begin{array}{c}\text { FFS monk seals } \\
(1995-2002) \text { (present study) }\end{array}$ \\
\hline
\end{tabular}


prey. This competition was most evident for adult male seals feeding among predatory fish aggregations at the summits of neighboring banks. Juvenile seals with CRITTERCAMS encountered fewer predatory fish, probably because most stayed at FFS Atoll, where observed predatory fish densities were lower than at the bank summits (Fig. 4). Only 1 juvenile seal left the atoll for the neighboring banks, and all of its recorded video was spent at depths deeper than $100 \mathrm{~m}$. Juveniles do not have the body mass of adults and thus are less effective at digging or flipping over large rock fragments to obtain prey (Parrish et al. 2005); consequently, their exposed prey may be more available to competing predatory fish.

The degree of competition that has historically occurred between monk seals and predatory fish is unknown. It is difficult to determine whether prey types have changed or if competition has intensified. Food limitations have been proposed as a result of oceanographic regime shifts that have lowered regional productivity (Polovina et al. 1994, Antonelis et al. 2003, Baker et al. 2007). If true, low productivity may have intensified competition between seals and predatory fish for limited prey. Given the large population of predatory fish in the NWHI and their dietary overlap with the seal, an increase in competition could impact the seals. The magnitude of the impact would depend on the population sizes of predatory fish, and there are few population estimates for NWHI. The most comprehensive, in situ diver estimates of predatory fish densities (for sharks and jacks pooled) across the NWHI range from 30 to 140 predators ha ${ }^{-1}$ with FFS in the middle (50 ha-1; Holzwarth et al. 2006). It is unknown to what degree these densities were inflated because the predatory fish were attracted to the survey divers. At this point, all population estimates of predatory fish should be regarded with caution. Future studies will need to investigate how historic commercial fishing may have influenced the competition level in the seals' foraging landscape. It is possible that fishing activities have served to both reduce and intensify competition between seals and assemblages of predatory fish. For example, fishing of jacks and other reef fish in the NWHI occurred at varying levels from the 1920s to the 1950s (Uchida 1979) before the shallow reefs of the region were made refuges (mid 1970s) to protect wildlife, including monk seals. The absence of directed fishing for jacks and sharks in the following decades has maintained predatory fish populations at high levels. Populations of predatory fish may also have grown due to ingestion of discarded undersize lobsters or bait from the region's 20 yr lobster trap fishery (F. Parrish pers. obs.). This fishery was closed in 2000 (DiNardo \& Moffitt 2007), ending the fishery discards and perhaps increasing competition between predatory fish and monk seals. Currently, a very limited bottomfish fishery removes Aprion virescens with other members of the deep slope bottomfish complex; and occasionally, jacks and sharks are caught as bycatch.

The fishing effort in the NWHI does not compare to the intense fishing pressure exerted broadly across the marine ecosystem of the main Hawaiian Islands, which has reduced the observed biomass of sharks and jacks seen on diver surveys to less than a tenth of that reported for NWHI surveys (DeMartini \& Friedlander 2006). The removal of predators from the main Hawaiian Islands may reduce competition between seals and predatory fish, and could explain why main Hawaiian Island seals are in excellent body condition and seals in the protected NWHI are emaciated (Antonelis et al. 2006). Future research should address the causes of these patterns and the possibility that inter-specific competition is impacting the survivorship of juvenile seals.

Acknowledgements. We thank National Geographic Mission Programs, whose collaboration made this work possible. Grants from the National Fish and Wildlife Foundation funded work to support some redesign of the CRITTERCAMS. Invaluable logistical support and assistance was provided by the US Fish and Wildlife Service Hawaiian Islands National Wildlife Refuge, specifically the staff of the French Frigate Shoals, Tern Island Field Station. Thoughtful reviews and comments were provided by C. Littnan, E. DeMartini, and 3 anonymous reviewers. This research was conducted under Marine Mammal Protection Act, NMFS Permit 848-1335 and US Fish and Wildlife Service Permits HWN 05-98, 1252102011.

\section{LITERATURE CITED}

Abernathy K (1999) Foraging ecology of Hawaiian monk seals at French Frigate Shoals, Hawaii. MS Thesis, University of Minnesota, St Paul, MN

Aguirre AA, Keefe TJ, Reif JS, Kashinsky L and others (2007) Infectious disease monitoring of the endangered Hawaiian monk seal. J Wildl Dis 43:220-241

Antonelis GA, Baker JD, Polovina JJ (2003) Improved body condition of weaned Hawaiian monk seal pups associated with El Niño events: potential benefits to an endangered species. Mar Mamm Sci 19:590-598

Antonelis GA, Baker JD, Johanos TC, Braun RC, Harting A (2006) A Hawaiian monk seal: status and conservation issues. Atoll Res Bull 543:75-101

Baker JD, Johanos TJ (2002) Effects of research handling on the endangered Hawaiian monk seal. Mar Mamm Sci 18:500-512

> Baker JD, Harting AL, Johanos TC (2006) Use of discovery curves to assess abundance of Hawaiian monk seals. Mar Mamm Sci 22:847-861

Baker JD, Polovina JJ, Howell EA (2007) Effect of variable oceanic productivity on the survival of an upper trophic predator, the Hawaiian monk seal Monachus schauinslandi. Mar Ecol Prog Ser 346:277-283 
Chave EH, Mundy BC (1994) Deep-sea fish of the Hawaiian Archipelago, Cross Seamount, and Johnston Atoll. Pac Sci 48:367-409

Craig MP, Ragen TJ (1999) Body size, survival, and decline of juvenile Hawaiian monk seals, Monachus schauinslandi. Mar Mamm Sci 15:786-809

DeCrosta MA, Taylor Jr. LR, Parrish JD (1984) Age determination, growth, and energetics of 3 species of carcharhinid sharks in Hawaii. In: Grigg RW, Tanone KY (eds) Proc 2nd Symp Resource Investigations in the Northwestern Hawaiian Islands. UNIHI-Seagrant MR-84-01, 75-95

DeLong RL, Kooyman GL, Gilmartin WG, Loughlin TR (1984) Hawaiian monk seal diving behavior. Acta Zool Fenn 172:129-131

DeMartini EE, Friedlander AM (2006) Predation, endemism, and related processes structuring shallow-water reef fish assemblages of the Northwestern Hawaiian Islands. Atoll Res Bull 543:237-256

DiNardo GT, Moffitt RB (2007) The Northwestern Hawaiian Islands lobster fishery: A targeted slipper lobster fishery. In: Lavalli KL, Spanier E (eds) The biology and fisheries of the slipper lobster. CRC Press, Boca Raton, FL, p 243-261

Ellis DM, DeMartini EE (1995) Evaluation of a video camera technique for indexing abundances of juvenile pink snapper, Pristipomoides filamentosus, and other Hawaiian shelf fishes. Fish Bull (Wash DC) 94:67-77

Friedlander AM, DeMartini EE (2002) Contrasts in density, size and biomass of reef fishes between the northwestern Hawaiian Islands: the effects of fishing down apex predators. Mar Ecol Prog Ser 230:253-264

Gilmartin WG, Eberhardt LL (1995) Status of the Hawaiian monk seal (Monachus schauinslandi) population. Can J Zool 73:1185-1190

Gilmartin WG, Johanos TC, Eberhardt LL (1993) Survival rates for the Hawaiian monk seal (Monachus schauinslandi). Mar Mamm Sci 9:407-420

Goodman-Lowe G (1998) Diet of Hawaiian monk seal (Monachus schauinslandi) from the Northwestern Hawaiian islands during 1991-1994. Mar Biol 132:535-546

Holzwarth SR, DeMartini EE, Schroeder RE, Zgliczynski BJ, Laughlin JL (2006) Sharks and jacks in the Northwestern Hawaiian Islands from towed-diver surveys 2000-2003. Atoll Res Bull 543:257-303

Kelley C, Ikehara W (2006) The impacts of bottomfishing on Raita and West St. Rogatien Banks in the Northwestern Hawaiian Islands. Atoll Res Bull 543:305-317

Littnan CL, Baker JD, Parrish FA, Marshall GJ (2004) Effects of video camera attachment on the foraging behavior of immature Hawaiian monk seals. Mar Mamm Sci 20:345-352

Longenecker K, Dollar RA, Cahoon M (2006) Increasing taxonomic resolution in dietary analysis of the Hawaiian monk seal. Atoll Res Bull 543:103-113

Lowe CG, Weatherbee BM, Meyer CG (2006) Using acoustic telemetry monitoring techniques to quantify movement patterns and site fidelity of shark and giant trevally around French Frigate Shoals and Midway Atoll. Atoll Res Bull 543:281-303

Marshall GJ (1998) Crittercam: An animal borne imaging and data logging system. Mar Tech Soc 32:11-17

Meyer CG, Holland KN, Papastamatiou YP (2007a) Seasonal and diel movements of giant trevally Caranx ignobilis at remote Hawaiian atolls: implications for the design of Marine Protected Areas. Mar Ecol Prog Ser 333:13-25
Meyer CG, Papastamatiou YP, Holland KN (2007b) Seasonal, diel, and tidal movements of green jobfish (Aprion virscens, Lutjanidae) at remote Hawaiian atolls: implications for marine protected area design. Mar Biol 151: 2133-2143

Parrish FA (2006) Precious corals and subphotic fish assemblages. Atoll Res Bull 543:425-438

Parrish FA, Abernathy K (2006) Movements of monk seals relative to ecological depth zones in the lower northwestern Hawaiian Islands. Atoll Res Bull 543:115-130

> Parrish FA, Boland RC (2004) Habitat and reef-fish assemblages of bank summits in the Northwestern Hawaiian Islands. Mar Biol 144:1065-1073

Parrish FA, Craig MP, Ragen TJ, Marshall GJ, Buhleier BM (2000) Identifying diurnal foraging habitat of the endangered Hawaiian monk seals using a seal-mounted video camera. Mar Mamm Sci 16:392-412

Parrish FA, Abernathy K, Marshall GJ, Buhleier BM (2002) Hawaiian monk seals (Monachus schauinslandi) foraging in deep-water coral beds. Mar Mamm Sci 18:244-258

Parrish FA, Marshall GJ, Littnan CL, Heithaus M and others (2005) Foraging of juvenile monk seals at French Frigate Shoals, Hawaii. Mar Mamm Sci 21:93-107

Polovina JJ, Mitchum GT, Graham NE, Craig MP, DeMartini EE, Flint EN (1994) Physical and biological consequences of a climate event in the central North Pacific. Fish Oceanogr 3:15-21

Ragen TJ, Lavigne DM (1999) The Hawaiian monk seal: biology of an endangered species. In: Twiss J, Reeves R (eds) Conservation and management of Marine Mammals Smithsonian Institution Press, Washington, DC

Randall JE (2007) Reef and shore fishes of the Hawaiian Islands. Sea Grant College Program, University of Hawaii, Honolulu

Reif JS, Bachand AM, Aguirre AA, Kashinsky L, Borjesson R, Braun R, Antonelis GA (2004) Morphometry, hematology and serum chemistry in the Hawaiian monk seal (Monachus schauinslandi). Mar Mamm Sci 20: $851-860$

Schlexer FV (1984) Diving patterns of the Hawaiian monk seal, Lisianski Island, 1982. US Department of Commerce, NOAA Tech Memo NMFS-NMFS-SWFSC-41

- Schmelzer I (2000) Seals and seascapes: covariation in Hawaiian monk seal subpopulations and the oceanic landscapes of the Hawaiian Archipelago. J Biogeogr 27: 901-914

Siegel S, Castellan NJ (1988) Nonparametric statistics for the behavioral sciences, 2nd edn. McGraw-Hill, New York

Stewart BS, Antonelis GA, Baker JD, Yochem PK (2006) Foraging biogeography of Hawaiian monk seals in the Northwestern Hawaiian Islands. Atoll Res Bull 543:131-145

Sudekum AE, Parrish JD, Radtke RL, Ralston S (1991) Life history and ecology of large jacks in undisturbed, shallow, oceanic communities. Fish Bull (Wash DC) 89:493-513

Tagawa AW, Tam CKM (2006) Hawaii's ulua and papio tagging project 2000 to 2004. State of Hawaii, Divison of Aquatic Resources. DAR Tech Rep 06-01

Thresher RE, Colin PL (1986) Trophic structure, diversity and abundance of fishes of the deep reef (30-300 m) at Enewetak, Marshall Islands. Bull Mar Sci 38:253-272

Uchida RN (1979) A summary of environmental and fishing information of the Northwestern Hawaiian Islands. Southwest Fisheries Center, National Marine Fisheries Service, Honolulu, HI. Administrative Report 4H, January 1977
Editorial responsibility: Brendan Godley,

University of Exeter, Cornwall Campus, UK
Submitted: October 27, 2007; Accepted: March 6, 2008

Proofs received from author(s): April 26, 2008 